\title{
Da voz e da imagem nos telefones de João \\ Cabral de Melo Neto
}

\author{
Voice and image on João Cabral de \\ Melo Neto's phones
}

Fabiana Renata Borsato ${ }^{1}$

RESUMO

João Cabral de Melo Neto reitera temas, figuras e ritmos em suas obras poéticas. A figura do telefone adquire plasticidade para transmitir tanto o medo e a morte quanto a luz, a constância e a inteireza da mulher-cidade, sendo imagem presente em obras diversas do poeta. Este estudo pretende comentar alguns desses poemas que apresentam a figura do telefone para compreender a rede de relações sintáticas, semânticas e rítmicas promovida por Cabral para tecer narrativas do feminino e do onírico.

Palavras-chave: João Cabral de Melo Neto; poesia discutida; reescrita.

\section{ABSTRACT}

João Cabral de Melo Neto reiterates themes, images and rhythms in his poetic works. The figure of the telephone acquires plasticity to transmit both fear and death, as well as light, constancy and integrity of the city-woman, being an image present in several works of the poet. This study intends to comments on some of these poems that present the image of the telephone to understand the network of syntactic, semantic and rhythmic relations promoted by Cabral to weave the narratives of the feminine and the oneiric.

Keywords: João Cabral de Melo Neto; discussed poetry; rewritten.

1 Universidade Estadual Paulista Júlio de Mesquita Filho, UNESP, Araraquara, São Paulo, Brasil e ILCML - Instituto de Literatura Comparada da Universidade do Porto, Porto, Portugal. E-mail: fabiane.borsato@unesp.br 
Mas o construtor, que agora faço surgir, encontra diante de si, como caos e matéria primitiva, precisamente a ordem do mundo que o Demiurgo extraiu da desordem inicial. A Natureza está formada, os elementos separados; mas algo a ele se impõe, impelindo-o a considerar inacabada essa obra que deverá ser remodelada e mobilizada para satisfação mais especial do homem. ${ }^{2}$

$\mathrm{R}$ etomadas temáticas e rítmicas são frequentes na poesia de João Cabral. Os temas da migração, da seca, do fazer artístico, da linguagem poética, das paisagens; as imagens do rio, da faca, da pedra, de Sevilha e do Nordeste brasileiro são recorrentes na poesia do autor. A imagem do "telefone”, emblema tecnológico da comunicação a partir de fins do século XIX, responsável pelo contato virtual rápido e eficaz, aparece por primeira vez no livro de estreia, Pedra do sono, em três poemas que apresentam marcas oníricas e que parecem interligados por um viés metapoético e por uma atmosfera de medo, morte, contradições que insinuam o contexto bélico de produção e publicação dos poemas dessa obra - a Segunda Guerra Mundial.

2 VALÉRY, Paul. Eupalinos ou o arquiteto = Eupalinos ou L'Architecte. Tradução de Olga Reggiani. Rio de Janeiro: Editora 34. Edição bilíngüe francês/português, 1996, p.171. 
"Poema deserto" é o primeiro texto a anunciar a figura do telefone. Quando o eu-poético diz que "Nem mesmo pelo telefone/me jogavam uma bomba."3, há certo apelo ao objeto mediador entre poeta e espaço exterior, sendo que o primeiro espera que do telefone surja uma bomba e algo venha a acontecer nesse espaço fechado, contraditório e ilógico de ação e reação em

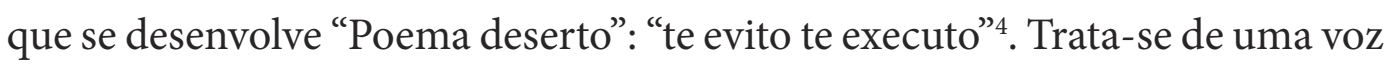
poética que se enuncia na primeira pessoa do singular, confessa sua paralisia frente aos fatos que ocorrem longe dali e à revelia de sua vontade, enumera um conjunto de ações contraditórias e aniquiladoras na estrofe final, cita a voz de um outro que assume entoação interrogativa e hipotética: "Por que não um tiro de revólver/ ou a sala subitamente às escuras?" , mas não retoma a imagem do telefone, ficando essa restrita ao sexto verso.

No mesmo livro, encontra-se o intrigante poema "O regimento", que aproxima espaço bélico e poemas transcritos pela comunidade para serem guardados pelos soldados sob pratos de refeições. O primeiro terceto desse poema finaliza com o verso "(Tais gritos ao telefone não perturbavam o silêncio.)" ${ }^{\prime \prime}$. Aparentemente não há coesão entre os versos que compõem a primeira estrofe porque o verso 1 não apresenta verbo e utiliza o recurso da enumeração para instaurar imagens em um cenário; o verso 2 menciona uma explosão da noite no eu-poético, seguida de uma frase que não apresenta evidente conexão com a referida explosão: "Não creio necessário"; e o último verso, pela presença dos parênteses que expressam informação acessória, pode ser lido como um acréscimo de dado ao verso anterior, ou seja, o de que a voz em discurso direto, indiciado pelo travessão, foi modulada em som agudo, estridente, mas que, surpreendente e ilogicamente, não perturbou o silêncio: "O estudo, o trabalho, o relógio na torre./ - A noite explodiu em mim? Não creio necessário./ (tais gritos ao telefone não perturbavam o silêncio.)"”

Entre o eu e o nós, o poema expressa vozes diversas, situações bélicas e transcrições poéticas aparentemente inconciliáveis com soldados e laranjas. Assim como no poema anterior, a figura do telefone em "O regimento" restringe-se à moldura dos parênteses do terceiro verso, na inusitada emissão de um grito insonoro que junto com outros procedimentos (como a presença de três períodos interrogativos e de elipses verbais em todo o poema) desencadeiam cenas próximas do nonsense.

O mesmo não acontecerá no terceiro poema de Pedra do sono, que apresenta em seu léxico o termo telefone reiterado quatro vezes. Trata-

3 MELO NETO, João Cabral de. Pedra do sono. In: Obra Completa. Rio de Janeiro: Nova Aguilar, 1999, p.44.

4 Ibidem, p. 44.

5 Ibidem, p. 44.

6 MELO NETO, João Cabral de. Pedra do sono. In: Janeiro: Nova Aguilar, 1999, p.52.

7 Ibidem, p. 52.

8 Ibidem, p. 52. 
F. R. BORSATO

Da voz e da imagem nos

telefones de João

Cabral de Melo

Neto

se de "O poeta". Nele, o telefone apresenta asas e se relaciona com imagens estranhas como a do pássaro-trovão. Até o acender da noite, anunciado na estrofe final, serão perturbadoras as imagens que descem do telefone do poeta: vozes sem cabeça, susto, medo, morte de neve. A segunda quadra ainda mantém a imagem do telefone, mas a ela acrescenta um novo traço que dá a ver um objeto alado que divide o verso e o espaço com o poeta: "O telefone com asas e o poeta"'.

O segundo verso dessa mesma estrofe intensifica a atmosfera onírica do poema ao promover certa hesitação sobre a identidade do sujeito da oração, se é o telefone com asas ou o poeta, pois ambos estão presentes no verso de abertura da quadra e estarão presentes em todas as estrofes, sendo que o termo poeta será reiterado cinco vezes, além da presença no título do poema, o que promove uma espécie de equivalência entre as imagens devido ao protagonismo que adquirem no texto poético:

\section{O poeta}

No telefone do poeta
desceram vozes sem cabeça
desceu um susto desceu o medo
da morte de neve.
O telefone com asas e o poeta
pensando que fosse o avião
que levaria de sua noite furiosa
aquelas máquinas em fuga.
Ora, na sala do poeta o relógio
marcava horas que ninguém vivera.
O telefone nem mulher nem sobrado,
ao telefone o pássaro-trovão.
Nuvens porém brancas de pássaros
acenderam a noite do poeta
e nos olhos, vistos por fora, do poeta
vão nascer duas flores secas. ${ }^{10}$

Vê-se que o telefone é figura reiterada em três estrofes. Na primeira, ele tem a função de deslocamento de elementos perturbadores; na segunda adquire equivalência visual com um pássaro e, somado à figura do poeta, uma

9 Ibidem, p. 52 .

10 MELO NETO, João Cabral de. Pedra do sono. In. Janeiro: Nova Aguilar, 1999, p.52-53. 
possível mudança de função, gerada pela expectativa de um deslocamento reverso dos elementos presentes na "noite furiosa", nomeados "máquinas em fuga". Na terceira quadra do poema, o telefone transmite a figura/ som do pássaro-trovão que será parcialmente retomada na última quadra, nas nuvens brancas de pássaros que acendem a noite e consequentemente fazem brotar flores secas dos olhos do poeta. Nesse poema, é notório o procedimento de discussão de imagens que tem por núcleo a figura sinérgica e cinética do telefone. Sua força sinérgica associa elementos contrários e inusitados como "vozes sem cabeça", "pássaro-trovão", "máquinas em fuga" e é núcleo promotor de um movimento oscilatório de transmissão e retomada de termos, em cooperação com a figura do poeta. A cinética, recorrente no processo composicional de João Cabral, depura o material poético e funciona como uma engrenagem sintática que avança e retorna, instaura relações de coordenação e subordinação entre os versos, mantém, acrescenta e altera as figuras nucleares mobilizadas no poema. Em Pedra do sono, alguns elementos da dinâmica da poesia de João Cabral já estão presentes, aquilo que a crítica literária reconhecerá, no conjunto da obra do poeta como uma "confluência, em tensão continuada, de um tom expositivo e um andamento narrativo na composição do poema." ${ }^{11}$ e que está fundamentado no trabalho sintático com as imagens poéticas.

A discussão de imagens, segundo João Cabral, é procedimento adotado com base nos estudos que realizou dos poetas metafísicos ingleses, quando trabalhou no Consulado de Londres, em 1950. Sendo assim, Pedra do sono, publicada em 1941, é obra anterior às leituras praticadas na Inglaterra. Entretanto, vemos que Cabral pratica o procedimento desde o livro de estreia. O termo telefone está presente no conjunto de três poemas de viés metapoético e, gradativamente, essa figura assume maior protagonismo, aparecendo, junto com a figura do poeta, em três das quatro estrofes de "O poeta", sendo ambas imagens reiteradas e ressignificadas verso a verso para compor o espaço onírico do poema.

Em 1959, portanto após a estada em Londres, João Cabral publica a obra Quaderna e nela o signo telefone reaparece para transmitir imagens completamente diversas daquelas presentes em Pedra do sono. Em lugar das incômodas e contrastantes figuras oníricas, da atmosfera beligerante, das conexões ilógicas entre espaços interiores e exteriores de Pedra do sono, o telefone de Quaderna transmitirá a luz interna da figura feminina e sensual com a qual dialoga o eu-poético de "Paisagem pelo telefone". O telefone continua a desempenhar o papel de mediador de fatos e interlocutores, mas a imaginação literária concentra seu olhar/audição nas descrições de corpos/ paisagens femininas, na expectativa de presença dessa que "nada embacia," e

11 SUSSEKIND, F. Com passo de prosa: voz, figura e movimento na poesia de João Cabral de Melo Neto. In. . A voz e a série. Rio de Janeiro: Sette Letras; Belo Horizonte: Ed. UFMG, 1998, p.47. Grifo da autora. 
F. R. Borsato Da voz e da imagem nos telefones de João Cabral de Melo

Neto para isso, o poeta mobiliza o signo telefone, o abandona por algumas estrofes para desdobrar outros campos semânticos e o retoma no verso 29:

\section{Paisagem pelo telefone}

1. Sempre que no telefone

2. me falavas, eu diria

3. que falavas de uma sala

4. toda de luz invadida,

5. sala que pelas janelas,

6. duzentas, se oferecia

7. a alguma manhã de praia,

8. mais manhã porque marinha,

9. a alguma manhã de praia

10. no prumo do meio-dia,

11. meio-dia mineral

12. de uma praia nordestina,

13. Nordeste de Pernambuco,

14. onde as manhãs são mais limpas,

15. Pernambuco do Recife,

16. de Piedade, de Olinda,

17. sempre povoado de velas,

18. brancas, ao sol estendidas,

19. de jangadas, que são velas

20. mais brancas porque salinas,

21. que, como muros caiados

22. possuem luz intestina,

23. pois não é o sol quem as veste

24. e tampouco as ilumina,

25. mais bem, somente as desveste

26. de toda sombra ou neblina,

27. deixando que livres brilhem

28. os cristais que dentro tinham.

29. Pois, assim, no telefone

30. tua voz me parecia

31. como se de tal manhã

32. estivesses envolvida,
Revista Letras,

Curitiba, UFPR,

n. 101, pp. 116-134,

jul./dez. 2020

ISSN 2236-0999

(versão eletrônica) 
33. fresca e clara, como se

34. telefonasses despida,

35. ou, se vestida, somente

36. de roupa de banho, mínima,

37. e que por mínima, pouco

38. de tua luz própria tira,

39. e até mais, quando falavas

40. no telefone, eu diria

41. que estavas de todo nua,

42. só de teu banho vestida,

43. que é quando tu estás mais clara

44. pois a água nada embacia,

45. sim, como o sol sobre a cal

46. seis estrofes mais acima,

47. a água clara não te acende:

48. libera a luz que já tinhas. ${ }^{12}$

"Paisagem pelo telefone" apresenta, no título, dois substantivos semanticamente contrários que adquirem relação de complementaridade. Paisagem, de ordem visual e táctil divide o título com telefone, signo de ordem auditiva que adquire no poema a capacidade de gerar som e imagem, pois se ao telefone cabe a transmissão da voz, ao poeta cabe fazer desse som um símile. Para dar a ver a luz proveniente do corpo feminino, o poema faz do telefone meio de dissecção da imagem-paisagem. Não há um ponto-defuga a limitar a visão do leitor, mas duzentas janelas dilatadoras do olhar. A simultaneidade e os paralelismos impedem qualquer limitação e oferecem mobilidade às imagens justapostas. Em lugar da tridimensionalidade que, "em sua ilusão, exige a fixação do espectador num ponto ideal"13, Cabral pluraliza os dominantes do poema e insere duzentas janelas hiperbólicas numa só sala, procedimento equivalente ao anunciado pelo crítico João Cabral, no ensaio "Joan Miró", em que analisa a pintura do catalão. Isso equivaleria a dizer que em "Paisagem pelo telefone" há, de modo similar ao que ocorre na pintura de Miró, uma sucessão de figuras dominantes, "que se propõem simultaneamente, pedindo do espectador uma série de fixações sucessivas, em cada uma das quais lhe é dado um setor do quadro." ${ }^{14}$. No poema, essas figuras

12 MELO NETO, João Cabral de. Quaderna. In: . Obra Completa. Rio de Janeiro: Nova Aguilar, 1999, p. 225-227. Os versos foram numerados para facilitar a identificação quando mencionados neste estudo.

13 MELO NETO, João Cabral de. Joan Miró. In. . Obra Completa. Rio de Janeiro: Nova Aguilar, 1999, p. 692.

14 Ibidem, p. 697. 
F. R. BORSATO

Da voz e da imagem nos telefones de João Cabral de Melo

Neto

adquirem coesão porque estão interligadas por uma sintaxe coordenativa ou subordinativa. À estaticidade das figuras, João Cabral oferece o dinamismo sintático e plástico, cria uma rede de palavras que avançam e retornam, aparecem e desaparecem, começam e recomeçam, intensificando a luz das coisas e da voz que fala ao telefone.

Em relação ao ritmo do poema, o acento tônico, na maioria dos versos, recai sobre as sílabas 3 e 7 ou 4 e 7 , o que lhe oferece uma cadência rítmica binária, e oscilações acentuais típicas da redondilha maior. Assim como as imagens desencadeadas sucessivamente na sintaxe do texto, e simultaneamente na memória, a cadência rítmica encantatória estimula a repetição e a relação intrínseca entre som e figuras, verificável desde a primeira estrofe, quando a imagem "sala" está implícita nas assonâncias em /a/ do verso 2 e no signo faLAvAS que possui em seu interior o anagrama de "sala". A reincidência do signo "falavas" no terceiro verso, seguido de "sala", parece antecipar a imagem da interlocutora nua que fala ao telefone, no espaço de uma sala.

Para alcançar essa imagem, o poema faz uso de recorrências e paralelismos. A palavra "telefone" está presente no título e nos versos $1 \mathrm{e}$ 40. O verbo "falavas" aparece nos versos 2, 3 e 39. O pronome "eu" mais o verbo "diria" fazem paralelismo nos versos 2 e 40 . Os versos 7 e 9 formam par idênticos. O signo "luz" está nos versos 4, 22, 38, 48, além dos muitos sinônimos ou termos análogos a esse signo, como: janelas, manhã, meio-dia, brancas, sol, caiados, ilumina, brilhem, cristais, clara, cal, acende; e dos antônimos sombra, neblina. Os paralelismos constroem a isotopia da claridade capaz de dar a ver a paisagem pelo telefone que tem por núcleo a interlocutora despida. Do conjunto de imagens, somente três possuem luz intestina: a interlocutora, as velas ao mar e os muros caiados. As demais são "invadidas" pela "luz". Trata-se de uma paisagem que, no princípio, se ocupa da luz invasora, mas, gradativamente, descobre a luz dos cristais internos que permitem ver a interlocutora não mais oculta, como nos versos iniciais, mas presentificada em "tu" (v. 43), único pronome do caso reto que faz referência à mulher despida.

$\mathrm{Na}$ estrofe 8, após o movimento de expansão das imagens rumo à paisagem exterior, há a recuperação da imagem e condição inicial da voz ao telefone. Essa retomada do signo auditivo não significa o abandono do visual que continua prevalecendo na descrição da voz fresca e clara, despida de todo excesso, precisa e mínima como uma manhã ensolarada. Tal dispositivo é ativado quando as várias imagens mobilizadas começam a se afastar da imagem nuclear - o corpo feminino que fala ao telefone. Então, o poeta recupera o elo entre as imagens. Esse recurso também acontece na estrofe final que faz referência à sexta estrofe do poema, quando a "luz intestina" aparece pela primeira vez de forma explícita no poema. O verso de encerramento também recupera o elemento luminoso: libera a luz que já tinhas. Da "pintura" 
justaposta de sala, janelas, manhã, praia e muros caiados surge a luz intestina que equivale à imagem feminina da mulher-poesia.

Vê-se que o recurso que Cabral conceitua como poesia discutida dáse em "Paisagem pelo telefone" pela retomada de termo ou expressão da estrofe anterior, à maneira do leixa-pren empregado em cantigas medievais. Conforme afirmado acima, quando do estudo dos poemas de Pedra do sono, a retomada do termo telefone, em "O poeta", viabiliza a hipótese de que João Cabral colhe da tradição literária o procedimento evidenciado na lírica medieval, o que pode ser reforçado pelo conhecimento que o poeta possuía da poesia medieval espanhola e da literatura popular do Nordeste brasileiro.

O poeta também se interessou pela "destreza intelectual e/ou capacidade associativa" ${ }^{15}$ dos poetas metafísicos ingleses, definida como wit. A crítica do wit ficou dividida em relação a seu emprego, ora considerando as associações geniais, ora achando-as excessivas por "forçar ideias heterogêneas a coexistirem"16. Predominam na obra de João Cabral as associações de imagens pertencentes a campos semânticos díspares. As sucessivas avaliações críticas do conceito chegaram ao traço surpresa do wit como importante elemento comunicativo. Trata-se de um trabalho expressivo e intelectual com a linguagem que gerou desconfiança dos românticos, sob o argumento de se tratar de uma "falta de espontaneidade." ${ }^{17}$, lembrando que Cabral preferia o cálculo e o controle de seu métier à espontaneidade e ao improviso. Eliot, em sua revisão crítica do conceito de wit e da poesia metafísica, realizada no ensaio The Metaphysical Poets (1921), afirma que os metafísicos apresentam "sensuous thought" em uma aura de "wit", o que controla o excesso de paixão e de sentimentos, bem como a exagerada seriedade, mobilizando o autocontrole do intelecto alerta. João Cabral, ao dialogar com essa tradição literária, mobiliza imagens literárias inusitadas que aproximam o corpo feminino do muro caiado, ambos núcleos de luz interior. Além disso, pelo recurso da retomada, "Paisagem pelo telefone" repete palavras e expressões da estrofe anterior, num encadeamento de imagens coesas no espaço do poema porque trabalhadas de modo a gerar restabelecimentos, atenuações, intensificações, temporalização estendida, traços da situação agradavelmente sedutora em que se encontra o eu-poético que escuta a voz e a descreve.

Percebe-se que todo o poema apresenta reiterações de termos interestróficos e intraestróficos, com a presença de anáfora e anadiplose. Cabral também mobiliza classes gramaticais promotoras de relações entre termos dos versos, tais como o pronome relativo, as conjunções alternativas, aditivas, explicativas e comparativas, os advérbios de intensidade e de negação. Tudo

15 LIMA, José Luís Araújo. A poesia dos Metafísicos: modos da expressão e o efeito de "awareness". Revista da Faculdade de Letras. Línguas e Literaturas. - Porto. - 2a série, v.1 (1984), p.248.

16 Ibidem, p. 248.

17 Ibidem, p. 249. 


\section{F. R. BORSATO}

Da voz e da imagem nos

telefones de João Cabral de Melo

Neto

está cuidadosamente interligado na trama sintática, e esses dispositivos da linguagem são mobilizados para a construção da imagem complexa do corpo de luz. O poema parte da chamada telefônica, realizada no espaço privativo de uma sala, para expandir a imagem rumo ao exterior praiano da paisagem recifense, discutida até o verso 29 , quando a conjunção "pois" e a repetição do termo "telefone" concentra a atenção na voz-imagem ao telefone. Inicia-se o processo de desnudamento da imagem. Pelo recurso da retificação, o eupoético despe a imagem até alcançar a sua luz interior. A expressão "como se" (versos 31 e 33) oferece um traço ficcional passível tanto de revisão das impressões (versos 35 e 36) quanto de acréscimo de dados (versos 39 a 42) sob a intenção de depuração da imagem. A cadência rítmica encantatória associada às reiterações de algumas figuras distribuídas estrategicamente no poema e à estrutura sintática de caráter lógico-argumentativo são coerentes com o processo de ajustamento da imagem nos poemas de Cabral. O poeta prova, substitui, refuta, recupera figuras por meio do recurso da reiteração. Além disso, promove o diálogo entre obras ao praticar a permuta de ritmos e figuras. ${ }^{18}$

O signo telefone aparecerá em outros dois poemas que compõem a obra Sevilha andando, de 1993. Neles, a interlocutora que fala ao telefone é Sevilha personificada em corpo-cidade que desperta no eu-poético o desejo e a forte expectativa de contato. O primeiro poema apresenta dois blocos de três estrofes cada, assim divididos pela pontuação final de cada bloco, o que denota a conclusão de um período, ideia ou relato:

\section{Sevilha ao telefone}

\section{Falo a Sevilha: ao telefone. \\ 2. Ela, a qualquer hora do dia. \\ 3. Falo até quando ocupado, \\ 4. e está quase sempre Sevilha. \\ 5. Falo mesmo quando ela dorme \\ 6. (ah! poder despertar Sevilha!), \\ 7. porque sei sempre quem está \\ 8. no extremo da linha vazia:}

9. é um vazio vivo, habitado

Revista Letras,

Curitiba, UFPR,

n. 101, pp. 116-134,

jul./dez. 2020

ISSN 2236-0999

(versão eletrônica) 
10. por todo o zumbir que é Sevilha

11. mesmo dormida de todo:

12. O que é muito pouco por dia.

\section{Ligo o telefone e espero: \\ 14. melhor se não o atendessem. \\ 15. Então, é o respirar recado: \\ 16. Fala-me dormindo, e entendo}

17. e me diz tudo que acordada

18. por puro pudor não diria:

19. "Não imagines que sou menos

20. porque agora estou dormida;

21. tanto dormindo entre lençóis,

22. ou no telefone abstraída,

23. te respondo em mulher inteira,

24. mais que qualquer outra, Sevilha." ${ }^{19}$

O primeiro bloco de estrofes funciona como um intróito ao tema da constância de Sevilha ao telefone (versos 2 e 4) e da obsessão do eu-poético pela comunicação com ela (verso 5). O segundo bloco instaura a narração de um episódio em que o eu-poético telefona para Sevilha e, enquanto espera, afirma, no verso 14, o desejo de que Sevilha não o atenda, contradizendo o verso 6 do primeiro bloco que, entre parênteses, confessa de modo reservado: "(Ah! poder despertar Sevilha!),". Essa contradição estende-se para Sevilha que fala ao telefone, mas permanece dormida, motivo por que, segundo o eu-poético, ela confessa o que não diria se estivesse desperta. Sevilha atende ao apelo presente no verso 6 e sua voz assume o discurso direto, resultando no tom dramático dessa parte do poema devido à presença da voz confessional e íntima da interlocutora que apresenta ao eu-poético a sua condição de "mulher inteira".

As reiterações intra e interestróficas também são praticadas nesse poema, sendo que o termo "Sevilha" e seu substitutivo pronominal "ela", oculto ou não, aparecem em todas as estrofes. Além disso, há a repetição do campo semântico relativo à sonoridade, no termo "telefone" e nos verbos "falar", "dizer", "responder", "respirar", além da substantivação de "zumbir". Por outro lado, junto dessa coerência lexical e sintática está a surpreendente quebra de convenções da Sevilha que fala dormida, numa espécie de sonambulismo confessional. Nos versos 21 e 22, Sevilha inclusive questiona uma possível crença do eu-poético que desautoriza a voz que fala dormida ou absorta.

19 MELO NETO, João Cabral de. Sevilha andando. In: Obra Completa. Rio de Janeiro: Nova Aguilar, 1999, p.642-643. 


\section{F. R. BORSATO}

Da voz e da imagem nos

telefones de João Cabral de Melo

Neto
Além disso, o eu-poético aparece confuso porque quer e não quer despertá-la. Nesse sentido, o poema "Sevilha ao telefone" parece dialogar com "O poeta", de Pedra do sono. Eles se aproximam pelos traços contraditórios e ilógicos. Enquanto no primeiro, isso se deve ao contexto bélico, no outro parece ser uma concessão à figura feminina e a seu poder encantatório. Em qualquer condição, Sevilha é mulher inteira e singular.

Outro aspecto a discutir é o emprego do pretérito imperfeito em "Paisagem pelo telefone", o que oferece a ideia de ação inconclusa, pertencente a um passado ainda presente e em processo. O poema "Sevilha ao telefone" emprega o tempo presente para apresentar a condição permanente de Sevilha: inteireza e singularidade, o que viabiliza essa imagem paradoxal de uma Sevilha desperta e adormecida, distante e próxima, que fala e dá a ver sua inteireza de cidade e de mulher.

Outro poema de Sevilha andando que apresenta similar mote é "Ainda Sevilha ao telefone", mas em lugar da voz da interlocutora Sevilha, o que se ouve é a dinâmica do funcionamento da cidade. Trata-se de um só episódio que se inicia novamente no desejo do eu-poético de falar com Sevilha pelo telefone e termina com a expansão sonora e a instauração de várias imagens que metaforizam o pulsar da cidade: relógio com vida, ácido vivo de ginja, pulsação longínqua, pregão de tudo, pragas de vizinhas, arfar de cidade:

\footnotetext{
Ainda Sevilha ao telefone

Quando pelo telefone

quero falar com Sevilha

e Sevilha, por acaso,

está no instante dormida,

deixo aberto o telefone

à concha de voz vazia:

ouço então no telefone

como relógio com vida,

toda uma vida passar

como o ácido vivo de ginja.

Ninguém fala ao telefone,

mas há pulsação longínqua;

onde há um pregão de tudo

onde há pragas de vizinhas,

e se ouve o arfar de cidade
}

Revista Letras,

Curitiba, UFPR, n. 101, pp. 116-134, jul./dez. 2020 ISSN 2236-0999 (versão eletrônica) 
A concha do telefone conecta espaços da cidade de Sevilha e desperta a memória do eu-poético que sente a pulsação vital de Sevilha, listada na estrofe final. Longe ou perto de Sevilha, no tempo presente ou pela mediação da memória, o eu-poético estabelece com ela uma relação afetuosa, estética, sensual. A paisagem e a cultura do lugar parecem promover a integração do eu poético com o espaço e seus elementos. Determinantes culturais e topográficos fazem de Sevilha um espaço do desejo e do bem-estar.

No livro Sevilha andando, os dois poemas mencionados, quando inter-relacionados, adquirem aspecto serial não só pela retomada temática, lexical, de versos e figuras, mas também pela repetição da ação de telefonar para Sevilha, marcada pela presença do advérbio "ainda".

A série, segundo Sussekind (1998), instaura no texto um acúmulo de detalhes e paralelismos que geram certa orientação narrativa. Quando lemos "Ainda Sevilha ao telefone", o advérbio do título anuncia a relação de implicação com "Sevilha ao telefone", interligando os episódios e gerando uma trama narrativa em que Sevilha ora atende ao chamado do eu-poético e lhe oferece a confissão de sua integridade e singularidade; ora não atende, mas permite que o eu-poético, conhecedor que é do ser de Sevilha, acesse a sua "pulsação longínqua". Assim como acontece no poema "Sevilha ao telefone", nesse último encontramos anáforas enumerativas da qualidade de Sevilha (versos 13 e 14); a retomada dos termos "telefone" e "Sevilha"; as rimas em /i/ predominantes nos versos pares de "Sevilha ao telefone" e de "Paisagem pelo telefone"; o episódio que relata a tentativa de interlocução entre o eu-poético e a cidade.

Em "Sevilha ao telefone", o eu-poético revela profundo conhecimento da interlocutora: "porque sei sempre quem está/ no extremo da linha vazia:" E a descreve brevemente, numa única estrofe, na sintética imagem do vazio vivo de Sevilha. Depois disso, assim como fazia habitualmente em Paisagem pelo telefone, o eu-poético telefona para Sevilha e aguarda que ela desperte para atendê-lo. E Sevilha não desperta, mas é capaz de falar adormecida e confessar sua intimidade.

Sevilha torna-se o núcleo que interliga os dois poemas. Em torno dessa imagem estarão as demais, satélites a expandir e qualificar a imagem nuclear. Nota-se um movimento que oscila entre o descontínuo da descrição de Sevilha e a sequencial narrativa do contato telefônico com ela. Os versos são combinados de modo a modificar ou a expandir a informação sobre a imagem, qualificando-a com relação ao tempo (a qualquer hora do dia,

20 MELO NETO, João Cabral de. Sevilha andando. In: Obra Completa. Rio de Janeiro: Nova Aguilar, 1999, p.646-647.

21 MELO NETO, João Cabral de. Sevilha andando. In: Obra Completa. Rio de Janeiro: Nova Aguilar, 1999, p. 643. 
F. R. BoRsATO

Da voz e da imagem nos telefones de João Cabral de Melo

Neto

quando, instante, relógio), ao modo (ocupado, dormida, vazio vivo), ao lugar cultural (pregão, pragas de vizinhas).

Lidos de modo conjunto, "Paisagem pelo telefone", "Sevilha ao telefone" e Ainda Sevilha ao telefone" formam uma narrativa do desejo de interlocução com esses corpos femininos. Desejo que inclui expansões superlativas de duzentas janelas e o falar adormecida. Retomados os telefones de Pedra do sono, vê-se que imagens e situações oníricas ainda podem ser mobilizados pelo telefone, mediador tanto de fatos perturbadores quanto da confissão de Sevilha enquanto dorme. Nos dois casos, o eu-poético e o poeta assumem o papel secundário de sujeito passivo diante dos acontecimentos e à mercê da "noite furiosa" ou de sujeito fascinado pela voz ao telefone.

Verifica-se que o telefone, em Pedra do sono, tem funções diversas, sendo que ora ele não promove a comunicação esperada ("Poema deserto"), ora transmite gritos oniricamente mudos ("O regimento"), ora apresenta a velocidade e o impacto do pássaro-trovão que aterrissa coisas-notícias assustadoras, capazes de secar as flores que nascem dos olhos do poeta. Vê-se que na primeira obra de Cabral, o telefone não cumpre seu papel de transmissor de vozes e mediador de diálogos ou, se o faz, oferece ao poeta passivo fatos perturbadores que parecem fazer referência ao contexto pavoroso da Segunda Guerra Mundial.

NolivroQuaderna, otelefoneéobjeto deuso contínuo para comunicação com a interlocução feminina, conforme anuncia o primeiro verso. Em lugar dos espaços angustiantes de Pedra do sono, o telefone de "Paisagem pelo telefone" transmitirá a voz da interlocutora que instigará a imaginação do eu-poético, responsável por uma série de imagens fartamente luminosas, desdobradas do espaço provável em que está a interlocutora: "uma sala/ toda de luz invadida,". Se antes, à revelia do poeta, desciam vozes sem cabeça, susto, medo e morte de seu telefone; agora o sistema coeso de imagens de luz advém da imaginação e do conhecimento que o eu-poético revela ter do corpo da interlocutora e de seu espaço de fala. As onze primeiras estrofes lançam hipóteses sobre o modo como a interlocutora está ao telefone. O poema desloca-se entre o saber e o imaginar. A voz da interlocutora ao telefone é responsável pela dinâmica das imagens mobilizadas no poema, ora sob a certeza do conhecido ${ }^{22}$, ora sob o crivo da imaginação que gera um movimento hipotético e sedutor, marcado pelas frases "eu diria", "me parecia", "como se" que buscam reunir as imagens capazes de representar o corpo feminino.

Três décadas depois, no livro Sevilha andando, João Cabral retoma o signo telefone. Apesar da proximidade evidente com o poema de Quaderna, tanto na discussão de imagens, nas rimas pareadas, no emprego da quadra,

22 Certeza expressa nos versos 17 ao 20 que mostram conhecimento da paisagem beiramar de Recife ou nos versos 21 e 22 que afirmam com veemência o modo de ser dos muros caiados, ainda no verso $43 \mathrm{em}$ que o eu poético afirma que nua a interlocutora fica "mais clara". 
quanto no desejo que o eu-poético possui pela interlocutora que agora é nomeada, trata-se de Sevilha; é curioso notar que nos dois poemas de Andando Sevilha, a interlocutora está adormecida e terá que ser despertada ou não. Conforme mencionado anteriormente, Sevilha toma a decisão de iniciar sua fala com o anúncio de um suposto juízo de valor do eu-poético que teria por premissa um certo rebaixamento daquele que dorme:

$$
\begin{aligned}
& \text { "Não imagines que sou menos } \\
& \text { porque agora estou dormida;"23 }
\end{aligned}
$$

Conhecendo o projeto poético de Cabral, sabemos que ele anunciou em "Considerações sobre o poeta dormindo", tese apresentada no Congresso de Poesia, realizado em Recife, em 1941, que o sono não inspira a poesia, mas pode fecundá-la enquanto linguagem à disposição do poeta:

\footnotetext{
A ação do sono sobre o poeta se dá em outro nível que o de simples material para o poema. Num terreno em que ele deixa de ser um objeto e se transforma como que num exercício, num apronto para o poeta (no sentido esportivo do termo), aguçando nele certas aptidões, certa vocação para o sobrenatural e o invisível, certa percepção do "sentido oculto das coisas inertes", da fórmula de Pedro Nava. ${ }^{24}$
}

Décadas mais tarde, depois da publicação de Sevilha andando, Cabral afirma a lucidez do poeta desperto, arquiteto do verso:

\footnotetext{
Para mim, a poesia é uma construção, como uma casa. Isso eu aprendi com Le Corbusier. A poesia é uma composição. Quando digo composição, quero dizer uma coisa construída, planejada de fora para dentro. Ninguém imagina que Picasso fez os quadros que fez porque estava inspirado. O problema dele era pegar a tela, estudar os espaços, os volumes. Eu só entendo o poético neste sentido. Vou fazer uma poesia de tal extensão, com tais e tais elementos, coisas que eu vou colocando como se fossem tijolos. É por isso que eu posso gastar anos fazendo um poema: porque existe planejamento. ${ }^{25}$
}

23 MELO NETO, João Cabral de. Sevilha andando. In: Obra Completa. Rio de Janeiro: Nova Aguilar, 1999, p.643.

24 MELO NETO, João Cabral de. Considerações sobre o poeta dormindo. In.

Obra Completa. Rio de Janeiro: Nova Aguilar, 1999, p.687.

25 MELO NETO, J.C. de. Considerações do poeta em vigília - entrevista. In: Cadernos de Literatura Brasileira - João Cabral de Melo Neto, Instituto Moreira Salles, no 1, mar 1996, p. 21. 


\section{F. R. BORSATO}

Da voz e da imagem nos telefones de João Cabral de Melo Neto

E Benedito Nunes sintetiza esse processo cabralino de aprendizagem da poesia ao anunciar que o poeta não se deixou levar pela poesia pura, tampouco pela poesia de sublimação do real, mas pela palavra-imagem que desdobrada em outras será capaz de representar o objeto:

(...) é a parte morta e calcinada da experiência subjetiva que a expressão lírica traz à tona da linguagem. Essa calcinação, que João Cabral hesitou em aceitar no seu valor de resto, de detrito, pareceu-lhe depois a condição mesma da passagem do psíquico ao poético, da poesia estado emocional à poesia como estado da linguagem, por obra da interferência voluntária da atenção que cristaliza a lembrança e os sentimentos desagregados ou putrefatos $(\ldots)^{26}$

Cabral não nega o sonho porque o vê como uma obra que pode ser reconstituída na linguagem do poema, mas na tese de 1941 afirma que o sonho só pode ser presença e imagem do poema se for percebido objetivamente, numa relação de implicação entre o que habita tanto a inconsciência quanto a consciência do poeta. Muitos estudos críticos leem o percurso poético cabralino em uma linha evolutiva que teria início em Pedra do sono (com as evidentes marcas oníricas e a presença recorrente do espaço noturno), passaria pela lucidez do sol do meio-dia culminante em $A$ educação pela pedra e assumiria o lúdico a partir da publicação da obra Museu de tudo, em que a narratividade e a enunciação em primeira pessoa seriam adotadas ${ }^{27}$. Entretanto, esses traços são encontráveis em toda a obra poética cabralina em menor ou maior medida porque são linhas de força de sua escrita. No último livro do poeta, a voz de Sevilha ao telefone parece desconstruir hierarquias e sugerir que sono e distração não a diminuem: "tanto dormindo entre lençóis,/ ou no telefone abstraída,/ te respondo em mulher inteira,/ mais que qualquer outra, Sevilha." ${ }^{28}$

Seguindo a lição dos poetas metafísicos, Cabral faz da vivência emocional a matéria de pensamento. As mais diversas experiências são trabalhadas de modo a gerar imagens poéticas aparentemente desconexas e inesperadas que se fazem semelhantes e coesas na poesia, à revelia da certeza de sua dessemelhança fora desse espaço. Segundo Calvino, "Em torno de cada imagem escondem-se outras, forma-se um campo de analogias, simetrias e

Revista Letras,

26 NUNES, Benedito. João Cabral de Melo Neto. Petrópolis: Editora Vozes, 1971, p. 57.

27 Conferir em BARBOSA, Joao Alexandre. "João Cabral: Museu de tudo e depois", Paisagem Tipográfica: homenagem a João Cabral de Melo Neto (1920-1999) - Revista Colóquio Letras, Lisboa, Fundação Calouste Gulbenkian, n. 157/158, jul.-dez 2000, p.159-181.

28 MELO NETO, João Cabral de. Sevilha andando. In: Janeiro: Nova Aguilar, 1999, p.643. Obra Completa. Rio de

Curitiba, UFPR,

n. 101, pp. 116-134,

jul./dez. 2020

ISSN 2236-0999

(versão eletrônica) 
contraposições."29. Desde Quaderna, o telefone passou a mediar as sensações e impressões de um eu-poético seduzido pelo corpo e modo de ser do objeto - mulher-cidade. Esse fascínio faz mobilizar figuras e campos semânticos que compõem com a maior precisão a imagem do corpo que se encontra no centro desse sistema de versos. Essa expansão descritiva parece guardar consigo o desejo de presença visual do objeto que se dá pela voz ao telefone e pelas imagens suscitadas no imaginário do interlocutor, marcas da obsessão metapoética de João Cabral. As variações sintáticas e as potencialidades semânticas das palavras oferecem uma visão precisa e plural do corpo descrito. É uma estrutura acumulativa porque aumenta gradativamente a rede de palavras e diversifica as perspectivas sobre o objeto. Lê-se "Paisagem pelo telefone" de outra forma quando relacionado com "Sevilha ao telefone" e o mesmo é possível dizer da leitura desse último em relação com "O poeta", de Pedra do sono. João Cabral reordena a imagem verso a verso, poema a poema, promove a pluralidade de "frames" e de apreensões visuais em busca de novas perspectivas sobre o objeto.

Para isso, Cabral tensiona o objeto e o observador, põe em relação o que se dá a ver por meio da voz e aquele que quer ver, aquele que vê e como vê o que é visto. E para isso, convoca na tradição literária os recursos expressivos que satisfaçam a sua exigente poética, numa constante reescrita de temas, imagens e ritmos para "satisfação mais especial do homem"30 que somos todos os leitores de sua poesia.

29 CALVINO, Ítalo. Visibilidade. In: . Seis propostas para o próximo milênio - lições americanas. Tradução de Ivo Barroso. São Paulo: Companhia das Letras, 1990, p. 104.

30 Conforme epígrafe de Paul Valéry do início deste texto. 
F. R. BoRsATO

Da voz e da imagem nos telefones de João Cabral de Melo Neto

\section{Referências}

BARBOSA, João Alexandre. João Cabral: Museu de tudo e depois. In: Paisagem Tipográfica: homenagem a João Cabral de Melo Neto (1920-1999) Revista Colóquio Letras, Lisboa: Fundação Calouste Gulbenkian, n. 157/158, p. 159-181, jul.-dez. 2000.

CALVINO, Ítalo. Visibilidade. In: Seis propostas para o próximo milênio - lições americanas. Trad. Ivo Barroso. São Paulo: Companhia das Letras, 1990. p. 95-114.

LIMA, José Luís Araújo. A poesia dos Metafísicos: modos da expressão e o efeito de "awareness". Revista da Faculdade de Letras, Línguas e Literaturas, Porto, 2a série, v.1, p. 247-259, 1984. Disponível em: http://ler.letras.up.pt/ uploads/ficheiros/artigo3951.pdf . Acesso em: 13 set. 2020.

MELO NETO, João Cabral de. Pedra do sono. In: Obra Completa. Rio de Janeiro: Nova Aguilar, 1999, p.41-55.

Quaderna. In: Obra Completa. Rio de Janeiro: Nova Aguilar, 1999, p.217-268.

Sevilha andando. In: Obra Completa. Rio de Janeiro: Nova Aguilar, 1999, p.627-651.

Considerações sobre o poeta dormindo. In: Obra Completa. Rio de Janeiro: Nova Aguilar, 1999, p.683-688.

. Joan Miró. In. Obra Completa. Rio de Janeiro: Nova Aguilar, 1999, p. 689-720.

Considerações do poeta em vigília - entrevista. In: Cadernos de Literatura Brasileira - João Cabral de Melo Neto, Instituto Moreira Salles, n. 1, mar. 1996.

NUNES, Benedito. João Cabral de Melo Neto. Petrópolis: Editora Vozes, 1971.

SUSSEKIND, Flora. Com passo de prosa: voz, figura e movimento na poesia de João Cabral de Melo Neto. In: . A voz e a série. Rio de Janeiro: Sette Letras; Belo Horizonte: Ed. UFMG, 1998, p. 31-54.

A voz e a série. Rio de Janeiro: Sette Letras; Belo Horizonte: Ed. UFMG, 1998.

Revista Letras,

Curitiba, UFPR, n. 101, pp. 116-134, jul./dez. 2020 ISSN 2236-0999 
VALÉRY, Paul. Eupalinos ou o arquiteto = Eupalinos ou L'Architecte. Trad. de Olga Reggiani. Rio de Janeiro: Rio de Janeiro: Ed. 34, 1996. Edição bilíngue francês/português..

Recebido em: 14/09/2020

Aceito em: 06/11/2020 